\begin{tabular}{lll}
\hline Sij & $\begin{array}{c}\text { Studies in Humanities and Education } \\
\text { she@sabapub.com }\end{array}$ & $\begin{array}{l}\text { SHE } \\
(2020) 1(1): 21-39 \\
\text { https://doi.org/10.48185/she.v1i1.71 }\end{array}$ \\
\hline ISSN: 2709-9563 & \\
\hline
\end{tabular}

\title{
Freight Transport Service on International Trade with Its Implication for Global Competitiveness
}

\author{
Eyakem Fikru* \\ Department of Information and Mathematics, Faculty of Information and Informatics Technology \\ (Data Science), Kazan Federal University, Kazan and Postcode 420010, Russia \\ eyakemf@gmail.com \\ Gobu Eticha \\ Department of Business and Economics, Faculty of Management, Addis Ababa University, Addis \\ Ababa and Postcode 190340, Ethiopia \\ gobueticha@gmail.com
}

Received: $20.09 .2020 \quad$ • Accepted/Published Online: 20.11.2020 • Final Version: 18.12.2020

\begin{abstract}
Freight transportation is the process of conveying different types of goods from one point to another using a variety of transport modes. The main objective of this study was to assess the fright transport service on international trade with its implications for global competitiveness. A descriptive followed by a longitudinal research design was used. Secondary data were collected from international organizations policy, standards documents, and annual reports for the year 20072018 by using the two indexing systems. Moreover, a quantitative research approach had been used. The data were entered, manipulated, organized, and analyzed using Excel and SPSS. Both descriptive and inferential analyses were used to examine the extent of fright transport service and its implications on global competitiveness and the interrelationship between international trade and freight transport service with its implication on global competitiveness. According to the result, European countries highly dominated the top 10 world rank logistic performance. Therefore, these countries were devoted to providing maximum efficiency and commitments on the Six Logistics Performance Index (LPI) and 12 pillars of GCI pillars than the others. Besides both, LPI and GCI were linearly associated with each other except for the 2016 fiscal year. This improved that tread and logistic services had an association.
\end{abstract}

Keywords: International trade; Global competitiveness; logistic performance index; Global Competitive Index

\section{Introduction}

Transport has a key role in terms of ensuring economic growth and maximizing social development. The system is a key element in the logistics chain, it joins the separated

\footnotetext{
* Corresponding author: Eyakem Fikru, eyakemf@gmail.com
} 
activities. Freight transportation is the process of conveying different types of goods from one point to another using a variety of transport modes. The transport service industry comprises several modes which range from air, water, railways, pipelines and road transports. Pipelines are used to transport items which are liquids and gaseous in nature while air, water, and roads are used to transport goods and passengers. So, transportation is the process of conveying different types of passengers, goods, and services from one point to another using a variety of transport modes (Shewangizaw Dagmawi, 2009).

The integration of transportation services and interaction among the different modes of transport chain influences the success of international trade. Freight transportation is critical to economic growth in any country. Efficient freight transport and logistics systems can strengthen the business competitiveness of a country (Wisetjindawat, 2011). Truck, rail, water, air, and pipeline services provide a spectrum of competitive and complementary freight transportation options, with each mode offering advantages and disadvantages in terms of price, speed, reliability, accessibility, visibility, security, and safety (Brogan, Aeppli, Beagan, and Brown, 2013). An effective transport system in logistics activities could provide better logistics efficiency, reduce operation costs, and promote service quality (Shewangizaw Dagmawi, 2009).

The capacity of freight transport services is rising at a high rate and crossing international borders. Studies indicate that this growth in freight transport with resulting congestion of road transport made intermodal freight transport to be among high priority agenda among the public, private players, and academia (Bontekoning and Priemus, 2004). In that regard, this study tries to assess freight transport service and international trade with its implication for global competitiveness. In this topic the researchers tried to answer the following research questions:

1. What are the extent of freight transport service and its implications for global

competitiveness?

2. What is the relationship between international trade and freight transport service implication on global competitiveness?

As per the research questions and the topic of the study, the main objective of this study was to assess the fright transport service and international trade with its implications for global competitiveness; likewise, the specific objectives of the study were:

- To examine the extent of fright transport service and its implications on global competitiveness by using the (LPI);

- To examine the interrelationship between international trade and freight transport service with its implication on global competitiveness;

\section{Literature Review}

The term "transport services" is used broadly to denote any service that is useful in undertaking international merchandise goods. As goods are exchanged across national borders, demand for services that provide to that trade is likely to be created. The most tremendous mods in international transportation service are air, rail, and maritime transport 
services, which are crucial in physically moving goods from the exporting to the importing countries.

Transportation services are critical for how the supply chain functions, how raw materials get to factories, how goods get to markets, how food gets from farmers to kitchen tables, how peoples travel from original destinations and share their norms into others place and how energy products move from areas of production to areas of consumption (Nation, 2013). Therefore, freight transportation is critical to economic growth in any country. Efficient freight transport and logistics systems can strengthen the business competitiveness of a country (Wisetjindawat, 2011). Truck, rail, water, air, and pipeline services provide a spectrum of competitive and complementary to freight transportation options, with each mode offering advantages and disadvantages in terms of price, speed, reliability, accessibility, visibility, security, and safety (Brogan et al., 2013).

The significance of freight transport service is to stimulate both local and global economies or to simplifying international trade flow. As transport service volumes are ever-growing and the problems of accommodating the freight flow efficiently and sustainably are exposed to a real challenge. Effective transport service in logistics activities could provide better logistics efficiency, reduce operation costs, and promote service quality. There are many components of logistics that interact to impact supply chains and ultimately influence international trade flows. Transport is the single most expensive component of logistics; it joins the separated activities (Shewangizaw, 2009).

\subsection{Freight transport and competitiveness}

Competitiveness, as such, is not an established term in the lexicon of economics. It came into common use in the 1980s, when there was considerable public discussion about the rise of Japan as an exporting power and the rising tide of imports of manufactured goods began flowing into the United States. The term was generally used to mean the ability to compete with manufacturers in other countries. It was never precisely defined in economic terms; however, it is important to define competitiveness in clear economic terms so that it becomes measurable. It is also the case that thinking of economic performance only in terms of international competition is too narrow a concept (Laurence, 2015).

As the world manufacturers become more productive, they are better able to compete in global markets. As the internal manufacturing and distribution systems become more productive, the nation's standard of living rises. More and better goods are available to consumers using the same levels of labor and capital (Laurence, 2015). Therefore, these are more competitive goods, so more of them are likely to be exported. One effect of rising exports is that consumers get to choose among a wider array of goods, from both foreign and domestic sources.

\subsection{The measure of Logistics Performance}


The Logistic Performance Index (LPI) promotes the understanding of key issues and options for improvement of logistics performance. The LPI entails several components assessing the logistics environment: customs clearance performance, quality of transport infrastructure, competitive and efficient shipment process, logistics process quality, international tracing of shipments, and international shipments frequency. It also allows for the assessment of logistics performance trends while performance is measured through a five-point scale. The general LPI of a country is the weighted average of the abovementioned components. Besides, the LPI is a tool providing quantitative data on specific aspects of a country's export and import procedures, delivery times, and costs related to supply chains, customs clearance procedures, and the percentage of shipments subjected to physical inspection. Trade logistics in the global economy: the logistics performance index and its indicators (World Bank, 2012; Arvis et al, 2012).

Policy measures have a direct impact on a country's image as a business environment or foreign investment. The efficiency of the transportation system and inventory is directly related as higher turnover allows for a shorter delivery time, higher responsiveness to demand changes, and lower costs of transportation. On the other hand, transport infrastructure has a significant impact on the productivity and the cost structure of businesses (Haughwout, 2001).

The efficiency of the logistics systems is vital for ensuring economic development and attracting foreign investment. The index is applied for identification of the issues and opportunities as concerns each country's transport infrastructure, logistics, and supply chain efficiency. Countries at similar performance levels may have substantially different ranks, especially in the middle and lower country income ranges Organization for Economic Cooperation and Development (OECD) and International Transport Forum (ITF, 2016).

\subsection{The Global Competitiveness Index}

Competitiveness is a basic condition for the existence of a company or an enterprise and is realized as the ability to maintain and expand the assets of business owners (OECD, 2017). Regarding the consideration of this topic, by expanding market availability to the suppliers and customers, improved freight transportation creates more competition for all businesses. Over the long run, this enhanced competition can also lead to greater efficiency as all market participants are compelled to innovate and lower costs in the presence of additional competitors.

Global Competitiveness Index (GCI) is geared to explore the ability of an economy to compete in international competition. Since 2004, it has been shown by the World Economic Forum (WEF). Previously, the Growth Competitiveness Index (GCI) and the Concurrent Competitiveness Index (CCI) have been reported. In 2007, the methodology for calculating the Global Competitiveness Index was changed, and to evaluate the year-to-year changes, the past results were recalculated by a new methodology (Ivanová and Čepel, 2018). GCI consists of 12 pillars of competitiveness which are classified into three subindices based on the factors of production, efficiency, and innovation. Each of these pillars consists of 7-20 other sub-indicators. Some sub-indicators are evaluated based on available statistical data; others are the result of the Global Executive Opinion Survey (WEF, 2016).

The rated states are classified into three development stages and two "inter-levels", as the criterion is GDP per capita and the primary products export share of total export. In the first 
development stage, economies driven by production factors, there are classified countries whose GDP per capita is less than 2,000 USD and the primary products export share in total export is over $70 \%$. The sub-indexes weight in a proportion of 65:35:5 is applied for the countries in the first development stage. In the second stage, economies driven by efficiency, there are states whose GDP per capita is in the range of 3,000-8,999 USD, as the sub-indexes weights are in the proportion of 40:50:10. In the third stage, the economy driven by innovation, there are states with a GDP per capita of more than 17,000 USD and sub-indexes weights are 20:50:30 (WEF, 2016).

Innovation performance is essential for an economy to be strong, competitive, and resourceefficient on the world markets (Kaynak, Altuntas, and Dereli, 2017). Innovation performance is highly dependent on the economic agents' expectations regarding the future economic situation on domestic and international markets (Tomaszewski and Swiadek, 2017).

According to Tidd, Bessant, and Pavitt (2007), innovation contributes to achieving a competitive advantage in several aspects. The most important characteristics of innovations include a strong relationship between market performance and new products. New products help maintain market shares and improve profitability. Growth is also utilizing non-price factors such as design, quality, individualization, etc. ability to substitute outdated products like shortening product lifecycles. The innovation of processes that lead to production time shortening and speed up new product development in comparison to competitors.

\section{Method of the Research}

Descriptive studies are used to acquire information regarding the present status of the phenomena and to describe what exists with regards to variables in a scenario. Therefore, to assess the fright transport service and international trade with its implications for global competitiveness descriptive followed by longitudinal research design was applied. Longitudinal because of the data collected with some time intervals. Moreover, a quantitative research approach was applied in the study.

The researcher was used secondary sources for gathering data. The coverage of data for this particular study encompassed from 2007-2018. The competitive measure of logistics and trade has been done within two years globally. Therefore, 6 consecutive two years interval data had been collected regardless of the countries that did not have all available required data within the indicated duration.

In order to collect the LPI and GCI data, the researchers were used the World Bank Report, from the official Websites of the World Bank (WB) and associated organizations. Additional information's also were collected from different sources including the international organizations' policy and standards documents and international organizations' annual reports like World Bank report, World Trade Organizations (WTO), OECD, and United Nations Conference on Trade and Development, organizations' internal reports, publications, newspapers, journals, documents from respective government offices, etc.

Reliable logistics is indispensable to integrate global value chains and reap the benefit of trade opportunities for growth and poverty reduction. The ability to connect to the global logistics web depends on a country's infrastructure, service markets, and trade processes. Government and the private sector in many developing countries should improve these areas or face the large and growing costs of exclusion. According to the information from 
the World Bank report (2016), there are 160 countries worldwide that recorded their LPI and GCI within two years interval, out of which, the top first ten, lower ten countries had been selected purposively to evaluate their competitiveness using the two indexing systems.

After data were collected, data processing has been carried out. The raw data converted into a suitable form for analysis and interpretation. This has been achieved through sequences of activities including coding, entry, and tabulation. The objective has to check the completeness, internal consistency, and appropriateness of the data to each of the variables. Statistical analysis had been carried out by using Excel and SPSS (V.24).

Descriptive statistics such as mean, percentages, and frequency distributions, were employed to give a deeper analysis of data. Moreover, GCI and LPI indexes had been used to evaluate the trade and logistic services and their implication on global competitiveness. In order to assess the relationship between international trade and logistic service correlation analysis was employed.

\section{Data Analysis, Presentation, and Interpretation of Findings}

\subsection{Logistic Performance Index analysis}

The logistics sector is recognized as one of the core pillars of economic development. It allows for comparisons of the logistics performance of both the international and domestic trade across 160 countries. Table 1 which illustrated in the appendix showed that the first top 10 highest scorer countries in 2007. Accordingly, Singapore was the first best performer country, with a score of 4.19. The differing pace of progress was also seen in the ratings on the quality of domestic trade and transport infrastructure. For instance, in terms of the domestic logistic cost, Singapore was found in the least rank, 113. Rather Japan had a costefficient, low logistic transport cost, compared all over the top 10 LPI scorers. This implies that Singapore scored first due to the overall groove of attritions.

Due to the customs processing, Netherlands were found in the $2^{\text {nd }}$ top position followed by Singapore, whereas, its score was highest with the consideration of customs, infrastructure, and ease of shipment. In contrast, the United Kingdom and Japan had lowered LPI scorer countries compared with all the other top 10 LPI rankers. Even if the specified countries' average LPI scores were rapidly increased, their customs status varied once with the other. This implies that the countries taxation system was unstable during that period.

Regarding infrastructure Netherland score the top place as compared to other countries. Almost all of the listed countries took the first top 10 positions within all over the world, except Canada and the United Kingdom. This indicated that those countries had to aim to improve trade supporting infrastructure in their logistics services. This explanation may still be largely valid in the majority of ranked countries.

The shipment quality of those indicated countries was also found in the beast status. Most of the countries rank from 1 to10, except Switzerland. This implies that the logistic performance of the countries was also supported by the quality of the shipment. This finding also illustrates that in supply chain efficiency and reliability the logistics gap of the top scorers' countries was not that much real and persistent.

Moreover, reliability and timeliness are key considerations for logistics in global value chains. Indeed, the ability to ensure on-time delivery and clearance as reflected in the table 
below the majority of the top 10 LPI scorers' countries had better punctuality. Singapore took the first score; whereas, Canada was found in the bottom next to the United Kingdom. This also indicated that the supply chain of clearance and delivery of those countries were found in a better condition.

Contrarily, Table 2 showed in the appendix is exemplified the bottom 10 lower scorer performing countries in the 2007 fiscal year. As the result, Afghanistan was the worst logistics performing country with a score of 1.21. The distributions of data score and progress were also indicated the difference in the ratings on the quality of domestic logistic costs and transport infrastructure. For example, in terms of the domestic logistic cost Afghanistan was found in place of $40^{\text {th }}$, and followed by Timor-Leste. However, Chad attains the $1^{\text {st }}$ domestic score rank within the entire considered countries in the indicated period. Rather, Niger had a better lowering of domestic logistic cost as compared to the bottom10 lower scorer countries. Likewise, Tajikistan had a little better performance regarding transport infrastructure, as compared with these categories.

In terms of the taxation system, Myanmar had a better customs process than the other lowest bottom 10 scorer countries. In another dimension, Tajikistan had a slight difference in international shipment. In line with the logistics service quality and competence, Niger, Djibouti, and Myanmar were performing the same score and slightly the higher position, as compared to the other 10 lower-performing countries. Almost all of the listed countries recorded the very lowest performance in the indicated sectors.

Furthermore, tracking and tracing are key driver factors that determining for firms involved in global logistic chains. The lower 10 scorer countries had recorded the worst position in this factor. For instance, Guyana scores a bit better rank compared to the rest of the other competent; whereas, Afghanistan and Myanmar scored a very poor rank. Likewise, reliability and timeliness are vital considerations for firms involved in international supply chains. Even though this category was at the lower edged and income-economy countries, Niger had taken the $1^{\text {st }}$ position among the other lower 10 performing categories, not only from the lower edge countries but also attained the best score rank $85^{\text {th }}$ in the fiscal year.

Logistics Performance Index (LPI), the most comprehensive international comparison tool to measure the trade and transport facilitation friendliness of countries, of the 2010 fiscal year result illustrated that Germany had the first best-performing country with a score of 4.11. Regarding the customs clearance efficiency, Luxembourg was the $1^{\text {st }}$ tope 10 ranked countries, followed by Singapore and Germany; whereas, the foulest performing country was Switzerland.

Concerning the quality of infrastructure and developing modern trade processes, among the top 10 upper LPI scorers, Germany had taken the $1^{\text {st }}$ best performance, followed by Netherlands and Norway respectively. These imply that those countries were worked hard concerning quality infrastructure building for the freight transport service. Moreover, logistics service providers are key players to improve logistics and supply chain. Singapore was ranked $1^{\text {st }}$ among the top 10 LPI countries followed by Sweden with the logistic service provision; whereas, Belgium was the lowest performer from this category.

Logistics quality and competence are the other critical factor to evaluate the overall level of competence and quality of logistics services. On the topic of that, Switzerland took the $1^{\text {st }}$ 
rank among the top 10-upper performing countries, with its score of 4.27 followed by Sweden and Netherlands respectively.

Tracking and traceability are the main activity of the logistics sector as a whole; since all parties in the goods' supply chain are involved in this component and it can be regarded as one of the priority areas in trade logistics. As the study result illustrated, Switzerland took the $1^{\text {st }}$ rank followed by Belgium and Sweden among the Top 10 upper-performance countries in the tracking and traceability activists.

Timeliness of shipments is the schedule of in reaching destination measures, how reliably shipments meet the promised delivery times. The reliability of the supply chains is generally measured by the timeliness of the delivery day. Concerning timeliness of shipments performance, Luxembourg scored $1^{\text {st }}$ and followed by Poland and Germany across the top 10 performing countries. Of course, this implied that during the indicated duration those countries' logistic provision was on time.

In other way direction, the study was also evaluated the bottom 10 comprehensive LPI country status. The case of the efficiency of customs and border clearance measures in terms of speed, simplicity, and predictability when dealing with customs and other border agencies is illustrated in Table 4 in the appendix. On a comparative basis, Sierra Leone took $110^{\text {th }}$ crossways out of the 155 considered countries during the fiscal year. Logistics service providers have become key players and to improve logistics and supply chain. To realizing the phenomena, Rwanda had performed the $67^{\text {th }}$ rank among 155 countries, followed by Guinea-Bissau. Even if, both Rwanda and Guinea-Bissau were at the lower-income economics as well as categorized to the lower 10 LPI ranking countries, they got the best performing rate in the international shipments.

Moreover, Table 4 carries a case of logistic performance index attritions like logistics quality and competence, tracking and tracing, and timeliness, of the bottom 10 lowest LPI performer countries in the 2010 fiscal year. As the result illustrated most of the lower performers were from African countries. Due to the lower quality, these countries lead to high logistic service costs and a fragmented economy.

Better logistics performance and trade simplification are strongly connected to trade expansion, export diversification, attractiveness to foreign direct investment, and economic growth. Taking this consideration into account, the researchers evaluate the 2012 LPI scorer top and bottom 10 countries' conditions. As the result, Singapore was the first best LPI ranked country, with an overall score of 4.13. This indicated that Singapore replaces Germany and increases by one rank, as compared to the previous round fiscal year 2010.

The countries' LPI ensures the improvement of freight transport efficiency and identified options for better international cooperation. Subsequently, the element which helps to evaluate the logistic performance results in terms, customs processing among the country. Singapore was found in the $1^{\text {st }}$ top position, followed by Finland and Hong Kong South China. However, Japan and the United States were found in the lower position compared across the top 10 upper performance. As the result reviled, even if the indicated countries' average LPI scores were rapidly increased their customs status varied once with the other.

Customs clearance efficiency and service level are not only affecting the trade efficiency but also creates a great impact on the investment, employment, and even regional economic 
development of one country. Considering the top 10 upper custom clearance efficient countries on the indicated fiscal year, the $1^{\text {st }}$ best performer was Singapore, followed by Finland and Hong Kong South China. However, the lowest performer country, within the top 10, was the United States.

Regarding the logistic performance evaluation results of infrastructure among the countries, Germany found in the $1^{\text {st }}$ top best position followed by Singapore and Netherlands in 2012. However, on the situation of infrastructure facilities, Denmark and the United Kingdom were at a lower position as compared to the other top performance LPI scorers. Even the indicated countries average LPI scores were rapidly increased their customs status varied once with the other.

Correspondingly measuring international logistics performance is vital for efficient policy and operational regulations. The study result illustrated that Hong Kong South China was found in the top position followed by Singapore and the Netherlands. However, Japan and the United States were lower ranks in the factor of international shipment as compared to the other top 10 upper LPI scorers.

The LPI component for measuring the quality of logistics services and operations evaluates the general logistics level of a particular country. The basic indicator which helps to grade the logistic quality and competence performance level among the countries indicated that Finland was found on the $1^{\text {st }}$ top position, followed by Denmark. However, the United States and the United Kingdom were lower ranks to the Logistics quality and competence as compared with the top 10 upper performers.

The ability to track and trace consignments is important to identify the exact location and the route of each consignment up to its delivery to the end customer. Concerning the logistic performance evaluation results of tracking and tracing, Finland was found in the $1^{\text {st }}$ top best position, followed by Netherlands and United States. However, Japan and the United Kingdom were found in the lower position, as compared to the top 10 upperperformance LPI scorers. Similarly in the measure of the timeliness of the delivery, Singapore had found on the top position, followed by Germany and the United States; while, Netherlands and Finland were found in the lower.

Table 6, illustrated in the appendix, indicated that the bottom10 LPI scorers countries of the 2012 fiscal year. According to the result, Comoros was found in the lowest position of the category with a score of 2.14. Regarding customs efficiency, one of the functional components to evaluate countries' logistic progress, and this dimension is used as a comparative basis. Nepal was the only country among lower-income economies that performs a bit better than the other lower 10 LPI scorers followed by Sudan. Contrarily, Djibouti and Burundi were the lowest ranks concerning customs clearance as compared with all the lower10 performance LPI scorers in 2012.

The logistic performance evaluation results of infrastructure among the countries indicated that Sierra Leone was found in the $1^{\text {st }}$ position of the lower scorers; whereas, Chad and the Congo Republic were found in the worst lower position. Similarly, in the logistic performance level of international shipments, Haiti's were found on the bottom of the rank next to Eritrea. In general, the study findings illustrated that the logistic performances of lower-income countries were no improved till in this indicated period as the developed country did. 
In the case of tracking and tracing, within the lowest bottom, LPI scorer countries in 2012 Congo Rep. was found in the higher position, followed by Comoros. But, the worstperforming country was Chad. In general, the study result illustrated that those lower performers did not show any vast change in the tracking and tracing capacity. Likewise, concerning the frequency with which shipments reach consignees within scheduled or expected delivery times low income-economy countries like Haiti recorded a bottommost rank.

Table 7 shown in the appendix exemplified the top 10 upper LPI ranked countries in the year 2014. As the result indicated, Germany was found on the $1^{\text {st }}$ top best position with the rank of 4.12 followed by Netherlands and Belgium. However, Japan was the lowest scorer as compared with the top 10 high scorer countries. In summing up, through the indicated period the European countries dominated the highest logistic performance score.

Regarding the customs clearance process, Norway was scored $1^{\text {st }}$ with a score of 4.21 , followed by Germany and Singapore. But, Japan and the United States had recorded the lower rank for the core factors of customs clearance as compared with all the top 10 upperperformance LPI scorers in the year 2014.

The well-developed infrastructure reduces the effect of distance between regions, integrating the national market, and connecting it at low cost to markets in other countries and regions. Aiming to this factor, the researchers examined the logistic performance of infrastructure crossways of the countries. As the result, Germany scored the highest rank followed by Singapore and the Netherlands. Contrarily, Sweden and Luxembourg had recorded a lower rank for the core factors of infrastructure as compared with all the top 10 upper-performance LPI scorers in 2014.

Concerning the logistic performance measurement outcomes of international shipments of the country, Luxembourg had scored the highest position, followed by Belgium and Sweden; whilst, the United States and Norway were scored lower rank concerning with the top 10 upper LPI scorers.

The degree in which the performance of the freight transport service operations across modes in the supply chains meets stated service criteria on the importance of the LPI evaluation report in 2014 illustrated that Netherlands and Germany were found on the top position next to Norway. In contrast, Japan and Luxembourg had recorded a lower rank.

The logistic performance evaluation result of tracking and tracing evidenced that the United States was found in the top position next to Germany. However, Luxembourg and Norway were lower rank for the core factors of tracking and tracing as compared with all the top 10 upper performances LPI scorers in 2014.

Timeliness measurement entails the logistics performance operations of one county. Based on the LPI measurement and evaluation of this factor a country like Luxembourg was found in the top $1^{\text {st }}$ position. But, Japan and the United States were lower ranks for the core factors of timeliness as compared with all the top 10 upper performers LPI scorers as of the year 2014.

Regarding, the track processing of the lower 10 LPI ranked countries in 2014, Djibouti was found in the $134^{\text {th }}$ position; likewise, Congo Rep found the worst bottom position, $160^{\text {th }}$. In line with logistic infrastructure facilities as the trained of the LPI, rank indicated, globally, 
a gradual convergence of LPI was observed. But, most of the lower LPI scorer countries' logistic programs were declining or suspended. For example, Somalia ranked $160^{\text {th }}$ position next to Eritrea.

Regarding the customs and border clearance measure, the 2016 logistic performance evaluation results indicated that Singapore was found in the $1^{\text {st }}$ top position, followed by Germany and the Netherlands. Contrarily, Austria and United States were lower rank for the core factors of customs as compared with all the top 10 upper LPI scorer counterparts.

The 2016 logistic performance report, illustrated in table 9, also indicated that Germany scored $1^{\text {st }}$ and followed by the Netherlands; whereas, Austria and Belgium were lower ranks concerning infrastructure facilities, as compared with all the top 10 upper-performance LPI scorers. Likewise, regarding the logistic performance evaluations of international shipments, Luxembourg took the $1^{\text {st }}$ top position; while, the United Kingdom and the United States recorded on the lower rank in the category.

The Logistics quality and competence states of 2016 indicated that Germany took the $1^{\text {st }}$ top place followed by Sweden and the Netherlands. Yet, Luxembourg, Hong Kong South China had scored a lower rank. As like the previous year conditions, this year's average LPI scores were rapidly increased even the countries' customs status varied once with the other. Likewise, on the subject of tracking and tracing ability, Sweden was found in the $1^{\text {st }}$ position with the rank of 4.38 followed by Austria and Germany; whereas, Singapore and Hong Kong South China were found on the bottom rank as compared with all the top 10 upper performers. Similarly, regarding the timeliness evaluations, Luxembourg scored $1^{\text {st }}$ and Germany scored $2^{\text {nd }}$; whereas, Hong Kong South China and the United States were found in the bottom position of these groups. In general, the trained of the study data indicated that high LPI scorer countries logistic service provision duration improved from time to time.

Customs duty is one of the pillars which help to measure the logistic performance of one country. Out of the lower 10 performer countries, Mauritania took the top position after Singapore and Zimbabwe. The Syrian Arab Republic was the worst-performing country in this group. Still, the output confirmed that most of the lower performers were poorer income countries. Jointly, those lower LPI ranking countries were also hindered by the quality and availability of logistic infrastructure. For instance, Zimbabwe took $123^{\text {rd }}$ rank, followed by Tajikistan $130^{\text {th }}$ rank compared with all the recorded competent; likewise, the worst performer country was the Syrian Arab Republic; it ranked $160^{\text {th }}$.

The logistics quality and competence has also central to trade efficiency. For instance, under the consideration of logistic quality, Lesotho had taken $138^{\text {th }}$ rank followed by Zimbabwe $141^{\text {st }}$ rank among the lower top 10 LPI performers. Syrian Arab Republic record the worst performances ranked $160^{\text {th }}$. Jointly, the international shipment is the critical measure area that needs concrete improvement for the logistic performance. Logistics service providers have become key players and to improve logistics and supply chain. However, most countries had to get international linkage problems in the logistic provision; such as Sierra Leone had acquired subordinate rank among the lower LPI performer countries followed by Lao People Democratic Republic; whereas, the worst performing countries in 2016 were the Syrian Arab Republic.

In order to improve delivery lead time, as the 4 years trained illustrated economically lower countries struggle more. But, still, a country like the Syrian Arab Republic recorded a poor 
tracking and tracing record; likewise, Somalia was ranked the worst $160^{\text {th }}$ position among the lower LPI performer countries. In the same way, the reliability of the supply chains is generally measured by the timeliness of the delivery. However, countries like, Lao People Democratic Republic, Syrian Arab Republic, and Somalia were recorded poor timeliness delivery during 2016. LPI measures the effectiveness and efficiency of customs information in terms of speed, simplicity, and predictability. Considering that, the best-performing country in this measurement during 2018 was Germany. It had the $1^{\text {st }}$ rank with a score of 4.09, followed by Belgium and Singapore; while, the lower performing country, from this group, was Finland. Similarly, transport infrastructure is expected to have an impact on the logistic performance. Germany was the best-performing country with a rank of 4.37 . However, the lower performer country, from the top 10 upper perfuming countries was Belgium. Logistics quality and competence are also one of the important components to evaluate the LPI performance of one country. As illustrated in table 11 in the appendix, Germany was the best-performing country with scores of 4.31, followed by Sweden and Japan. However, the foulest performing country, from the group was Belgium. Linked with the international shipments, Belgium took the highest tip with a score of 3.99; whereas, Denmark scored the lowest rank in this category. Concerning the tracking and tracing, Finland was ranked $1^{\text {st }}$ with a score of 4.32 ; while, Netherlands performs lower compared with the top 10 upper LPI scorers countries within the year 2018. In line with timeliness, Belgium was scored $1^{\text {st }}$ followed by Denmark and German. However, Japan and the Netherlands have recorded a lower rank from the group. This study finding of the 2018 report also indicated that Madagascar and Bolivia were a better LPI overall scorer with a rank of 2.15 and 2.12 respectively comparatively with the entire bottom 10 performers. In contrast, the worst performer country was Afghanistan with a rank of 1.95. Similarly, in the customs clearing process, Madagascar was a score of 2.39 followed by Bolivia 2.36 which is moderate performer countries; while, Afghanistan performed the worst score of 1.85. Still, this finding also illustrated that lower-income countries had the poorest logistic performance. Regarding infrastructure, Fiji had a little better score within the bottom 10 performers; whereas, Afghanistan had the worst. On the subject of tracking and tracing, Madagascar had a moderate performance score of 2.61 within this category; but, Afghanistan scored lowest. Concerning the predictability of when the shipments will arrive, Bolivia was score a bit better with a score of 2.74 compared with the lower LPI performers, followed by Madagascar and Guyana. However, Burundi had recorded the least performance. In general, as the result illustrated the worst LPI scorer countries in 2018 were categorized in the least with economically lower, landlocked countries, small island states, and post-conflict countries.

\subsection{Relationship between international trade and logistic service}

To evaluate the association between international trade and logistic service implication on global competitiveness, the researcher uses LPI and GCI indexes. The 6 years survey data were used with two years intervals from 2007 up to 2018. The data were collected by the World Bank and its agent organization using an online structured survey. Both the LPI and GCI survey uses a standardized questionnaire which comprises domestic and international parts. So, those international organizations use these indexes for comparing once country 
trade and logistic performance with the others. Therefore, this study used those indexes in order to compare and contrast the relationship between international trade and logistic services.

A correlation analysis was used to examine the relationships and strengthens between LPI and GCI indexes. Accordingly, as the result illustrated most of the serious years LPI and GCI indexes were linearly associated except the 2016 result; because their p-values were lower than the corresponding significant threshold 0.05. Regarding the strangeness of the association, as the index comparison indicated starting from 2007 up to 2014 both the logistic and trade develop a strong positive association because the correlation coefficients of the selected indexes are above 0.7. This implies tread and logistic services had developed a strong association during those indicated times.

However, during 2016 the two indicators lose their relationship and in the next recent year, 2018, developed a weak negative association. This means during 2016 logistic activity and tread loses their association at all; whereas, in 2018 the trade activity inversely affected by logistic correspondent, i.e., if the logistic performance increases the tread performance would be drowned back.

Table 1. Pearson correlation matrix between international trade and logistic service

\begin{tabular}{lll}
\hline Year & & GCI \\
\hline 2018 & LPI & $-0.314^{* *}$ \\
2016 & Sig. & 0.003 \\
& LPI & -0.073 \\
2014 & Sig. & 0.497 \\
& LPI & $0.794^{* *}$ \\
2012 & Sig. & 0.000 \\
& LPI & $0.864^{* *}$ \\
2010 & Sig. & 0.000 \\
& LPI & $0.887^{* *}$ \\
2007 & Sig. & 0.000 \\
& LPI & $0.884^{* *}$ \\
\hline
\end{tabular}

\section{Conclusion}

Freight Transport service and international trade are one of the most expedient economic factors in pushing economies to transition and integration. The objectives of this paper had to provide theoretical justification based on LPI and GCI trends. In order to evaluate the extent of fright transport service and its implications on global competitiveness and to 
examine the interrelationship between international trade and freight transport service with its implication on the global competitiveness use the 6-year Logistics Performance Index (LPI) and equivalent GCI datasets, under the consideration of both the top and bottom 10 performers countries. As the trend flow illustrated European countries highly dominated the top 10 world rank, dominant logistic performers. Therefore, European countries were devoted to providing maximum efficiency and commitments on the Six LPI index as well as 12 pillars of GCI index than the others.

The index is applied for identification of the issues and opportunities as concerns each country's transport infrastructure, logistics, and supply chain efficiency. Countries at similar performance levels sometimes had substantially different ranks, especially in the middle and lower country income ranges. Likewise, reliability and timeliness are vital considerations for logistic international supply chains.

In other way direction, the bottom 10 lower-performing countries trend (2007-2018) explains that, inefficiency in the area of logistics infrastructures development, customs clearance and border management, competence and quality of logistics services, and timelines and international shipments consecutively. That is, because of poor economic efficiency, countries lose the competition and because of inefficiencies, lower-performing countries were exposed to high trade logistics costs that harmed the economies, particularly on local consumption, production, and export.

Regarding the relationship between freight transport service and global competitiveness, both of those factors were statistically significant. Since starting from 2007 up to 2014 both the logistic performance and global competitiveness develop a strong positive association. Therefore, during those periods tread and logistics moved in the same line. That is, if the logistic performance of the country improved forward, the trade competency also had escalated up. During 2016 the world logistic activity and tread lose their association at all; whereas, in 2018 the trade activity inversely affected the logistic correspondent, these indicate that, as globally competitiveness does not only depends on logistics performance but also other factors such as, supply chains complex systems with its complex processes, services in business, regulations constraints, politics, trade restriction, investment climate, perceptions of enterprises and policymaker, financial constraints and other problems like bilateral and regional trade agreements would affect tariffs and increase documentation, might have been the reason that causes the negative relationship between Logistic Performance and Global competitiveness. 


\section{References}

[1] Arvis, Jean-François; Mustra, Monica Alina; Ojala, Lauri; Shepherd, Ben; Saslavsky, Daniel. 2012. Connecting to Compete 2012: Trade Logistics in the Global Economy. World Bank. Washington, 70417:5-54. DOI:10986/12689

[2] Bontekoning, Y. \& Priemus, H., 2004. Breakthrough Innovations in Intermodal Freight Transport. Transportation Planning and Technology, Taylor \& Francis Journals, vol. 27(5), pages 335-345. doi: 10.1080/0308106042000273031

[3] Brogan J.J, Aeppli A.E, Beagan D.F \& Brown A. 2013, Freight Transportation Modal Shares: Scenarios for a Low-Carbon Future, Transportation Energy Futures Series. Prepared by Cambridge Systematics, Inc. (Cambridge, MA), and the National Renewable Energy Laboratory (Golden, CO) for the U.S. Department of Energy, Washington, DC. DOE/GO102013-3705. 80 pp. https://www.ourenergypolicy.org/wp-content/uploads/2013/11/55636.pdf

[4] Eva Ivanová \& Martin Čepel, 2018. The Impact of Innovation Performance on the Competitiveness of the Visegrad 4 Countries. Journal of Competitiveness, Vol. 10, Issue 1, pp. 54 - 72. DOI: $10.7441 /$ joc.2018.01.04

[5] Haughwout, A. F., 2001. Infrastructure and social welfare in metropolitan America. Economic Policy Review, Vol. 7, 3, 2001, pp. 43-54

[6] Kaynak, S., Altuntas, S., \& Dereli, T. (2017). Comparing the innovation performance of EU candidate countries: an entropy-based TOPSIS approach. Economic Research-Ekonomska Istrazivanja, 30(1)._31-54, DOI: 10.1080/1331677X.2016.1265895

[7] Laurence O’Rourke, Eric Beshers, \& Daniel Stock, 2015. Measuring the Impacts of Freight Transportation Improvements on the Economy and Competitiveness. U.S Department of Transportation, Hederal Highway Administration, USA. https://ops.fhwa.dot.gov/publications/fhwahop15034/fhwahop15034.pdf

[8] National (2013), Renewable Energy Laboratory; pp. 12-1-12-42. DOE International Energy StorageDatabase(beta).(2013).Policies.Retrievedfrom:http://www.energystorageexchange.org/pol icie.

[9] OECD, 2017. Global Economic Outlook. Retrieved from http://www.oecd.org/eco/ outlook/ sources-and-methods.html.

[10] OECD/ITF, 2016. Logistics development strategies and performance measurement. 158 Round Table Report. https://www.itf-oecd.org/sites/default/files/docs/logistics-strategy-performancemanagement.pdf

[11] Shewangizaw Dagmawi, 2009. Assessment of the Impact of Logistic Performance on Trade in Ethiopia. M.BA. Thesis, St Mary's University, Addis Ababa, Ethiopia. http://hdl.handle.net/123456789/1677

[12] Tidd, J., Bessant, J. \& Pavitt, K., 2007. Ř́zení inovací - zavádění technologických, tržních a organizačních změn. Brno: Computer Press, Czech, Business books, pp.1:549. ISBN 978-80-2511466-7. https://www.sciencedirect.com/science/article/pii/S2212567115003822\#bbib0055

[13] Tomaszewski, M, Swiadek A (2017) The impact of the economic conditions on the innovation activity of the companies from selected Balkan states. Economic Research-Ekonomska Istrazivanja, 30: 1896-1913. doi.10.1080/1331677X.2017.1398099.

[14] Wisinee Wisetjindawat 2011, Review of Good Practices in Urban Freight Transportation, Nagoya Institute of Technology $\quad$ Japan, 4 (80): https://www.unescap.org/sites/default/files/bulletin80_Article-3.pdf

[15] World Bank, 2012, "Connecting to Compete 2012 - Trade Logistics in the Global Economy - The Logistics Performance Index and Its Indicators". http://documents.worldbank.org/curated/en/567341468326992422/Connecting-to-compete-2012trade-logistics-in-the-global-economy-the-logistics-performance-index-and-its-indicators

[16] World Economic Forum, 2016. The Global Competitiveness Report 2016-2017. Retrieved from https://www.weforum.org/reports/the-global-competitiveness-report-2016-2017-1. 


\section{Appendix}

Table 1: Top 10 LPI Upper-Rank Scorer Countries, 2007

\begin{tabular}{|c|c|c|c|c|c|c|c|c|c|c|c|c|c|c|}
\hline \multirow[b]{2}{*}{ S/no } & \multirow[b]{2}{*}{ Country } & \multicolumn{7}{|c|}{ Overall LPI rank } & \multicolumn{2}{|c|}{ Customs } & \multicolumn{2}{|c|}{ Infrastructure } & \multicolumn{2}{|c|}{$\begin{array}{l}\text { Internationa } \\
\text { I shipments } \\
\end{array}$} \\
\hline & & score & $\begin{array}{l}\text { lower } \\
\text { bound }\end{array}$ & $\begin{array}{l}\text { upper } \\
\text { bound }\end{array}$ & rank & $\begin{array}{l}\text { lower } \\
\text { bound }\end{array}$ & $\begin{array}{l}\text { upper } \\
\text { bound }\end{array}$ & $\begin{array}{l}\% \text { of the } \\
\text { highest } \\
\text { performer }\end{array}$ & score & rank & score & rank & score & rank \\
\hline 1 & Singapore & 4.19 & 1 & 0.05 & 100 & 3.90 & 3 & 4.27 & 2 & 4.04 & 2 & 4.21 & 2 & 4.25 \\
\hline 2 & Netherlands & 4.18 & 2 & 0.04 & 99.6 & 3.99 & 1 & 4.29 & 1 & 4.05 & 1 & 4.25 & 1 & 4.14 \\
\hline 3 & Germany & 4.10 & 3 & 0.03 & 97.1 & 3.88 & 4 & 4.19 & 3 & 3.91 & 4 & 4.21 & 3 & 4.12 \\
\hline 4 & Sweden & 4.08 & 4 & 0.08 & 96.4 & 3.85 & 6 & 4.11 & 5 & 3.90 & 5 & 4.06 & 6 & 4.15 \\
\hline 5 & Austria & 4.06 & 5 & 0.11 & 96.0 & 3.83 & 8 & 4.06 & 8 & 3.97 & 3 & 4.13 & 4 & 3.97 \\
\hline 6 & Japan & 4.02 & 6 & 0.03 & 94.8 & 3.79 & 11 & 4.11 & 6 & 3.77 & 10 & 4.12 & 5 & 4.08 \\
\hline 7 & Switzerland & 4.02 & 7 & 0.08 & 94.5 & 3.85 & 5 & 4.13 & 4 & 3.67 & 14 & 4.00 & 8 & 4.04 \\
\hline 8 & Hong Kon. China & 4.00 & 8 & 0.04 & 94.1 & 3.84 & 7 & 4.06 & 9 & 3.78 & 7 & 3.99 & 9 & 4.06 \\
\hline 9 & UK & 3.99 & 9 & 0.03 & 93.8 & 3.74 & 13 & 4.05 & 10 & 3.85 & 6 & 4.02 & 7 & 4.10 \\
\hline 1 & Canada & 3.92 & 10 & 0.05 & 91.6 & 3.82 & 9 & 3.95 & 12 & 3.78 & 8 & 3.85 & 12 & 3.98 \\
\hline
\end{tabular}

Source: World Bank report 2007

Table 2: Lower 10 LPI Scorer Countries, 2007

\begin{tabular}{|c|c|c|c|c|c|c|c|c|c|c|c|c|c|c|}
\hline \multirow[b]{2}{*}{ S/no } & \multirow[b]{2}{*}{ Country } & \multicolumn{7}{|c|}{ Overall LPI rank } & \multicolumn{2}{|c|}{ Customs } & \multicolumn{2}{|c|}{ Infrastructure } & \multicolumn{2}{|c|}{$\begin{array}{l}\text { International } \\
\text { shipments }\end{array}$} \\
\hline & & score & $\begin{array}{l}\text { lower } \\
\text { bound }\end{array}$ & $\begin{array}{l}\text { upper } \\
\text { bound }\end{array}$ & $\begin{array}{l}\text { ran } \\
\mathbf{k}\end{array}$ & $\begin{array}{l}\text { lower } \\
\text { bound }\end{array}$ & $\begin{array}{l}\text { upper } \\
\text { bound }\end{array}$ & $\begin{array}{l}\% \text { of the } \\
\text { highest } \\
\text { performer }\end{array}$ & score & rank & score & rank & score & rank \\
\hline 141 & Guyana & 2.05 & 141 & 0.15 & 32.8 & 1.95 & 134 & 1.78 & 142 & 1.80 & 144 & 1.95 & 137 & 2.35 \\
\hline 142 & Chad & 1.98 & 142 & 0.16 & 30.8 & 2.00 & 133 & 1.80 & 141 & 1.83 & 142 & 1.82 & 143 & 1.91 \\
\hline 143 & Niger & 1.97 & 143 & 0.23 & 30.5 & 1.67 & 145 & 1.40 & 149 & 1.80 & 145 & 2.00 & 134 & 2.00 \\
\hline 144 & Sierra Leone & 1.95 & 144 & 0.21 & 29.9 & 1.58 & 149 & 1.83 & 140 & 1.82 & 143 & 1.91 & 140 & 2.00 \\
\hline 145 & Djibouti & 1.94 & 145 & 0.16 & 29.5 & 1.64 & 146 & 1.92 & 130 & 2.00 & 137 & 2.00 & 133 & 1.82 \\
\hline 146 & Tajikistan & 1.93 & 146 & 0.19 & 29.3 & 1.91 & 140 & 2.00 & 125 & 2.00 & 136 & 1.90 & 141 & 1.67 \\
\hline 147 & Myanmar & 1.86 & 147 & 0.17 & 27.0 & 2.07 & 124 & 1.69 & 145 & 1.73 & 146 & 2.00 & 135 & 1.57 \\
\hline 148 & Rwanda & 1.77 & 148 & 0.13 & 24.3 & 1.80 & 143 & 1.53 & 148 & 1.67 & 148 & 1.67 & 148 & 1.60 \\
\hline 149 & Timor-Leste & 1.71 & 149 & 0.23 & 22.3 & 1.63 & 147 & 1.67 & 146 & 1.50 & 149 & 1.60 & 149 & 1.67 \\
\hline 150 & Afghanistan & 1.21 & 150 & 0.10 & 6.6 & 1.30 & 150 & 1.10 & 150 & 1.22 & 150 & 1.25 & 150 & 1.00 \\
\hline
\end{tabular}

Source: World Bank report 2007

Table 3: Top 10 LPI Top Scorer Countries, 2010

\begin{tabular}{|c|c|c|c|c|c|c|c|c|c|c|c|c|c|c|}
\hline \multirow[b]{2}{*}{ S/no } & \multirow[b]{2}{*}{ Country } & \multicolumn{7}{|c|}{ Overall LPI rank } & \multicolumn{2}{|c|}{ Customs } & \multicolumn{2}{|c|}{ Infrastructure } & \multicolumn{2}{|c|}{$\begin{array}{l}\text { International } \\
\text { shipments }\end{array}$} \\
\hline & & score & $\begin{array}{l}\text { lower } \\
\text { bound }\end{array}$ & $\begin{array}{l}\text { upper } \\
\text { bound }\end{array}$ & rank & $\begin{array}{l}\text { lower } \\
\text { bound }\end{array}$ & $\begin{array}{l}\text { upper } \\
\text { bound }\end{array}$ & $\begin{array}{l}\% \text { of the } \\
\text { highest } \\
\text { performer }\end{array}$ & score & rank & score & rank & score & rank \\
\hline 1 & Germany & 4.11 & 4.07 & 4.16 & 1 & 1 & 4 & 100.0 & 4.00 & 3 & 4.34 & 1 & 3.66 & 9 \\
\hline 2 & Singapore & 4.09 & 4.01 & 4.17 & 2 & 1 & 4 & 99.2 & 4.02 & 2 & 4.22 & 4 & 3.86 & 1 \\
\hline 3 & Sweden & 4.08 & 3.90 & 4.25 & 3 & 1 & 10 & 98.8 & 3.88 & 5 & 4.03 & 10 & 3.83 & 2 \\
\hline 4 & Netherlands & 4.07 & 4.00 & 4.14 & 4 & 1 & 4 & 98.5 & 3.98 & 4 & 4.25 & 2 & 3.61 & 11 \\
\hline 5 & Luxembourg & 3.98 & 3.68 & 4.28 & 5 & 1 & 20 & 95.7 & 4.04 & 1 & 4.06 & 9 & 3.67 & 7 \\
\hline 6 & Switzerland & 3.97 & 3.84 & 4.11 & 6 & 2 & 17 & 95.5 & 3.73 & 12 & 4.17 & 6 & 3.32 & 25 \\
\hline 7 & Japan & 3.97 & 3.91 & 4.03 & 7 & 5 & 10 & 95.2 & 3.79 & 10 & 4.19 & 5 & 3.55 & 12 \\
\hline 8 & UK & 3.95 & 3.89 & 4.02 & 8 & 5 & 11 & 94.9 & 3.74 & 11 & 3.95 & 16 & 3.66 & 8 \\
\hline 9 & Belgium & 3.94 & 3.86 & 4.02 & 9 & 5 & 14 & 94.5 & 3.83 & 9 & 4.01 & 12 & 3.31 & 26 \\
\hline 10 & Norway & 3.93 & 3.72 & 4.14 & 10 & 1 & 19 & 94.2 & 3.86 & 6 & 4.22 & 3 & 3.35 & 24 \\
\hline
\end{tabular}




\begin{tabular}{|c|c|c|c|c|c|c|c|c|c|c|c|c|c|c|}
\hline \multirow[b]{2}{*}{ S/no } & \multirow[b]{2}{*}{ Country } & \multicolumn{7}{|c|}{ Overall LPI rank } & \multicolumn{2}{|c|}{ Customs } & \multicolumn{2}{|c|}{ Infrastructure } & \multicolumn{2}{|c|}{$\begin{array}{l}\text { International } \\
\text { shipments }\end{array}$} \\
\hline & & score & $\begin{array}{l}\text { lower } \\
\text { bound }\end{array}$ & $\begin{array}{l}\text { upper } \\
\text { bound }\end{array}$ & rank & $\begin{array}{l}\text { lower } \\
\text { bound }\end{array}$ & $\begin{array}{l}\text { upper } \\
\text { bound }\end{array}$ & $\begin{array}{l}\% \text { of the } \\
\text { highest } \\
\text { performer }\end{array}$ & score & rank & score & rank & score & rank \\
\hline 146 & Sudan & 2.21 & 1.84 & 2.57 & 146 & 105 & 153 & 38.7 & 2.02 & 139 & 1.78 & 144 & 2.11 & 151 \\
\hline 147 & Nepal & 2.20 & 2.01 & 2.40 & 147 & 126 & 152 & 38.6 & 2.07 & 131 & 1.80 & 143 & 2.21 & 143 \\
\hline 148 & Iraq & 2.11 & 1.87 & 2.34 & 148 & 132 & 153 & 35.5 & 2.07 & 130 & 1.73 & 147 & 2.20 & 144 \\
\hline 149 & Guinea-Bissau & 2.10 & 1.69 & 2.52 & 149 & 112 & 154 & 35.4 & 1.89 & 148 & 1.56 & 153 & 2.75 & 92 \\
\hline 150 & Cuba & 2.07 & 1.84 & 2.29 & 150 & 137 & 153 & 34.3 & 1.79 & 150 & 1.90 & 136 & 2.32 & 135 \\
\hline 151 & Rwanda & 2.04 & 1.73 & 2.34 & 151 & 132 & 153 & 33.4 & 1.63 & 153 & 1.63 & 150 & 2.88 & 67 \\
\hline 152 & Namibia & 2.02 & 1.63 & 2.41 & 152 & 125 & 154 & 32.8 & 1.68 & 152 & 1.71 & 148 & 2.20 & 145 \\
\hline 153 & Sierra Leone & 1.97 & 1.75 & 2.19 & 153 & 148 & 153 & 31.2 & 2.17 & 110 & 1.61 & 152 & 2.33 & 134 \\
\hline 154 & Eritrea & 1.70 & 1.34 & 2.06 & 154 & 151 & 155 & 22.4 & 1.50 & 154 & 1.35 & 155 & 1.63 & 154 \\
\hline 155 & Somalia & 1.34 & 1.05 & 1.63 & 155 & 155 & 155 & 10.9 & 1.33 & 155 & 1.50 & 154 & 1.33 & 155 \\
\hline
\end{tabular}

Source: World Bank report 2010

Table 5: Top 10 Upper LPI Scorer Countries, 2012

\begin{tabular}{|c|c|c|c|c|c|c|c|c|c|c|c|c|c|c|}
\hline \multirow[b]{2}{*}{ S/no } & \multirow[b]{2}{*}{ Country } & \multicolumn{7}{|c|}{ Overall LPI rank } & \multicolumn{2}{|c|}{ Customs } & \multicolumn{2}{|c|}{ Infrastructure } & \multicolumn{2}{|c|}{$\begin{array}{l}\text { International } \\
\text { shipments }\end{array}$} \\
\hline & & score & $\begin{array}{l}\text { lower } \\
\text { bound }\end{array}$ & $\begin{array}{l}\text { upper } \\
\text { bound }\end{array}$ & rank & $\begin{array}{l}\text { lower } \\
\text { bound }\end{array}$ & $\begin{array}{l}\text { upper } \\
\text { bound }\end{array}$ & $\begin{array}{l}\% \text { of the } \\
\text { highest } \\
\text { performer }\end{array}$ & score & rank & score & rank & score & rank \\
\hline 1 & Singapore & 4.13 & 4.06 & 4.19 & 1 & 1 & 2 & 100.0 & 4.10 & 1 & 4.15 & 2 & 3.99 & 2 \\
\hline 2 & $\begin{array}{l}\text { Hong Kong } \\
\text { South China }\end{array}$ & 4.12 & 4.05 & 4.19 & 2 & 1 & 2 & 99.9 & 3.97 & 3 & 4.12 & 7 & 4.18 & 1 \\
\hline 3 & Finland & 4.05 & 3.81 & 4.29 & 3 & 1 & 15 & 97.6 & 3.98 & 2 & 4.12 & 6 & 3.85 & 4 \\
\hline 4 & Germany & 4.03 & 3.97 & 4.09 & 4 & 3 & 7 & 97.0 & 3.87 & 6 & 4.26 & 1 & 3.67 & 11 \\
\hline 5 & Netherlands & 4.02 & 3.94 & 4.11 & 5 & 3 & 7 & 96.7 & 3.85 & 8 & 4.15 & 3 & 3.86 & 3 \\
\hline 6 & Denmark & 4.02 & 3.82 & 4.22 & 6 & 1 & 15 & 96.6 & 3.93 & 4 & 4.07 & 10 & 3.70 & 8 \\
\hline 7 & Belgium & 3.98 & 3.85 & 4.11 & 7 & 3 & 13 & 95.3 & 3.85 & 7 & 4.12 & 8 & 3.73 & 6 \\
\hline 8 & Japan & 3.93 & 3.88 & 3.99 & 8 & 7 & 11 & 93.8 & 3.72 & 11 & 4.11 & 9 & 3.61 & 14 \\
\hline 9 & United States & 3.93 & 3.88 & 3.98 & 9 & 8 & 11 & 93.7 & 3.67 & 13 & 4.14 & 4 & 3.56 & 17 \\
\hline 10 & UK & 3.90 & 3.84 & 3.96 & 10 & 8 & 14 & 92.7 & 3.73 & 10 & 3.95 & 15 & 3.63 & 13 \\
\hline
\end{tabular}

Source: World Bank report 2012

Table 6: The Bottom 10 LPI Scorer Countries, 2012

\begin{tabular}{|c|c|c|c|c|c|c|c|c|c|c|c|c|c|c|}
\hline \multirow[b]{2}{*}{ S/no } & \multirow[b]{2}{*}{ Country } & \multicolumn{7}{|c|}{ Overall LPI rank } & \multicolumn{2}{|c|}{ Customs } & \multicolumn{2}{|c|}{ Infrastructure } & \multicolumn{2}{|c|}{$\begin{array}{l}\text { International } \\
\text { shipments }\end{array}$} \\
\hline & & score & $\begin{array}{l}\text { lower } \\
\text { bound }\end{array}$ & $\begin{array}{l}\text { upper } \\
\text { bound }\end{array}$ & rank & $\begin{array}{l}\text { lower } \\
\text { bound }\end{array}$ & $\begin{array}{l}\text { upper } \\
\text { bound }\end{array}$ & $\begin{array}{l}\% \text { of the } \\
\text { highest } \\
\text { performer }\end{array}$ & score & rank & score & rank & score & rank \\
\hline 146 & Comoros & 2.14 & 1.92 & 2.36 & 146 & 130 & 153 & 36.5 & 2.00 & 141 & 1.94 & 145 & 1.81 & 153 \\
\hline 147 & Eritrea & 2.11 & 1.69 & 2.53 & 147 & 106 & 154 & 35.5 & 1.78 & 151 & 1.83 & 150 & 2.63 & 97 \\
\hline 148 & Sudan & 2.10 & 1.83 & 2.38 & 148 & 128 & 153 & 35.3 & 2.14 & 131 & 2.01 & 140 & 1.93 & 150 \\
\hline 149 & Congo, Rep. & 2.08 & 1.85 & 2.31 & 149 & 135 & 153 & 34.7 & 1.80 & 149 & 1.27 & 155 & 1.94 & 149 \\
\hline 150 & Sierra Leone & 2.08 & 1.80 & 2.36 & 150 & 130 & 154 & 34.5 & 1.73 & 153 & 2.50 & 88 & 1.85 & 152 \\
\hline 151 & Nepal & 2.04 & 1.74 & 2.33 & 151 & 134 & 154 & 33.1 & 2.20 & 125 & 1.87 & 149 & 1.86 & 151 \\
\hline 152 & Chad & 2.03 & 1.68 & 2.37 & 152 & 129 & 154 & 32.9 & 1.86 & 148 & 2.00 & 142 & 2.00 & 146 \\
\hline 153 & Haiti & 2.03 & 1.87 & 2.19 & 153 & 145 & 153 & 32.8 & 1.78 & 150 & 1.78 & 151 & 1.94 & 148 \\
\hline 154 & Djibouti & 1.80 & 1.58 & 2.02 & 154 & 154 & 155 & 25.5 & 1.72 & 154 & 1.51 & 154 & 1.77 & 154 \\
\hline 155 & Burundi & 1.61 & 1.29 & 1.93 & 155 & 154 & 155 & 19.5 & 1.67 & 155 & 1.68 & 153 & 1.57 & 155 \\
\hline
\end{tabular}

Table 7: Top 10 Upper LPI Scorer Countries, 2014

\begin{tabular}{|l|l|l|l|l|l|}
\hline S/no & Country & Overall LPI rank & Customs & Infrastructure & $\begin{array}{l}\text { International } \\
\text { shipments }\end{array}$ \\
\hline
\end{tabular}




\begin{tabular}{|c|c|c|c|c|c|c|c|c|c|c|c|c|c|c|}
\hline & & score & $\begin{array}{l}\text { lower } \\
\text { bound }\end{array}$ & $\begin{array}{l}\text { upper } \\
\text { bound }\end{array}$ & rank & $\begin{array}{l}\text { lower } \\
\text { bound }\end{array}$ & $\begin{array}{l}\text { upper } \\
\text { bound }\end{array}$ & $\begin{array}{l}\% \text { of the } \\
\text { highest } \\
\text { performer }\end{array}$ & score & rank & score & rank & score & rank \\
\hline 1 & Germany & 4.12 & 4.07 & 4.17 & 1 & 1 & 1 & 100.0 & 4.10 & 2 & 4.32 & 1 & 3.74 & 4 \\
\hline 2 & Netherlands & 4.05 & 3.97 & 4.12 & 2 & 2 & 5 & 97.6 & 3.96 & 4 & 4.23 & 3 & 3.64 & 11 \\
\hline 3 & Belgium & 4.04 & 3.96 & 4.13 & 3 & 1 & 6 & 97.5 & 3.80 & 11 & 4.10 & 8 & 3.80 & 2 \\
\hline 4 & UK & 4.01 & 3.96 & 4.07 & 4 & 2 & 5 & 96.6 & 3.94 & 5 & 4.16 & 6 & 3.63 & 12 \\
\hline 5 & Singapore & 4.00 & 3.95 & 4.06 & 5 & 2 & 7 & 96.2 & 4.01 & 3 & 4.28 & 2 & 3.70 & 6 \\
\hline 6 & Sweden & 3.96 & 3.68 & 4.24 & 6 & 1 & 20 & 94.9 & 3.75 & 15 & 4.09 & 9 & 3.76 & 3 \\
\hline 7 & Norway & 3.96 & 3.69 & 4.22 & 7 & 1 & 19 & 94.8 & 4.21 & 1 & 4.19 & 4 & 3.42 & 30 \\
\hline 8 & Luxembourg & 3.95 & 3.65 & 4.24 & 8 & 1 & 21 & 94.4 & 3.82 & 10 & 3.91 & 15 & 3.82 & 1 \\
\hline 9 & United States & 3.92 & 3.87 & 3.97 & 9 & 6 & 10 & 93.5 & 3.73 & 16 & 4.18 & 5 & 3.45 & 26 \\
\hline 10 & Japan & 3.91 & 3.85 & 3.97 & 10 & 6 & 12 & 93.4 & 3.78 & 14 & 4.16 & 7 & 3.52 & 19 \\
\hline
\end{tabular}

Source: World Bank report 2014

Table 8: The Bottom 10 LPI Scorer Countries, 2014

\begin{tabular}{|c|c|c|c|c|c|c|c|c|c|c|c|c|c|c|}
\hline \multirow[b]{2}{*}{ S/no } & \multirow[b]{2}{*}{ Country } & \multicolumn{7}{|c|}{ Overall LPI rank } & \multicolumn{2}{|c|}{ Customs } & \multicolumn{2}{|c|}{ Infrastructure } & \multicolumn{2}{|c|}{$\begin{array}{l}\text { International } \\
\text { shipments }\end{array}$} \\
\hline & & score & $\begin{array}{l}\text { lower } \\
\text { bound }\end{array}$ & $\begin{array}{l}\text { upper } \\
\text { bound }\end{array}$ & rank & $\begin{array}{l}\text { lower } \\
\text { bound }\end{array}$ & $\begin{array}{l}\text { upper } \\
\text { bound }\end{array}$ & $\begin{array}{l}\% \text { of the } \\
\text { highest } \\
\text { performer }\end{array}$ & score & rank & score & rank & score & rank \\
\hline 1 & Yemen, Rep. & 2.18 & 1.67 & 2.69 & 151 & 91 & 160 & 37.9 & 1.63 & 159 & 1.87 & 153 & 2.35 & 134 \\
\hline 152 & Cuba & 2.18 & 1.91 & 2.45 & 152 & 126 & 158 & 37.8 & 2.17 & 136 & 1.84 & 155 & 2.47 & 123 \\
\hline 153 & Sudan & 2.16 & 1.93 & 2.39 & 153 & 132 & 158 & 37.2 & 1.87 & 155 & 1.90 & 152 & 2.23 & 144 \\
\hline 154 & Djibouti & 2.15 & 1.80 & 2.50 & 154 & 117 & 159 & 36.8 & 2.20 & 134 & 2.00 & 150 & 1.80 & 158 \\
\hline 155 & Syrian Ar. Re. & 2.09 & 1.81 & 2.37 & 155 & 134 & 159 & 34.9 & 2.07 & 142 & 2.08 & 144 & 2.15 & 150 \\
\hline 156 & Eritrea & 2.08 & 1.78 & 2.39 & 156 & 132 & 159 & 34.7 & 1.90 & 153 & 1.68 & 159 & 1.90 & 157 \\
\hline 157 & Congo, Rep. & 2.08 & 1.83 & 2.33 & 157 & 139 & 159 & 34.5 & 1.50 & 160 & 1.83 & 157 & 2.17 & 148 \\
\hline 158 & Afghanistan & 2.07 & 1.97 & 2.16 & 158 & 153 & 158 & 34.3 & 2.16 & 137 & 1.82 & 158 & 1.99 & 156 \\
\hline 159 & Congo, De. R. & 1.88 & 1.60 & 2.15 & 159 & 154 & 160 & 28.2 & 1.78 & 158 & 1.83 & 156 & 1.70 & 160 \\
\hline 160 & Somalia & 1.77 & 1.32 & 2.23 & 160 & 149 & 160 & 24.8 & 2.00 & 147 & 1.50 & 160 & 1.75 & 159 \\
\hline
\end{tabular}

\begin{tabular}{|c|c|c|c|c|c|c|c|c|c|c|c|c|c|c|}
\hline \multirow[b]{2}{*}{ S/no } & \multirow[b]{2}{*}{ Country } & \multicolumn{7}{|c|}{ Overall LPI rank } & \multicolumn{2}{|c|}{ Customs } & \multicolumn{2}{|c|}{ Infrastructure } & \multicolumn{2}{|c|}{$\begin{array}{l}\text { International } \\
\text { shipments }\end{array}$} \\
\hline & & score & $\begin{array}{l}\text { lower } \\
\text { bound }\end{array}$ & $\begin{array}{l}\text { upper } \\
\text { bound }\end{array}$ & rank & $\begin{array}{l}\text { lower } \\
\text { bound }\end{array}$ & $\begin{array}{l}\text { upper } \\
\text { bound }\end{array}$ & $\begin{array}{l}\% \text { of the } \\
\text { highest } \\
\text { performer }\end{array}$ & score & rank & score & rank & score & rank \\
\hline 1 & Germany & 4.23 & 4.18 & 4.27 & 1 & 1 & 4 & 100.00 & 4.12 & 2 & 4.44 & 1 & 3.86 & 8 \\
\hline 2 & Luxembourg & 4.22 & 3.97 & 4.47 & 2 & 1 & 12 & 99.80 & 3.90 & 9 & 4.24 & 4 & 4.24 & 1 \\
\hline 3 & Sweden & 4.20 & 4.09 & 4.32 & 3 & 1 & 7 & 99.34 & 3.92 & 8 & 4.27 & 3 & 4.00 & 4 \\
\hline 4 & Netherlands & 4.19 & 4.11 & 4.27 & 4 & 1 & 6 & 98.81 & 4.12 & 3 & 4.29 & 2 & 3.94 & 6 \\
\hline 5 & Singapore & 4.14 & 4.06 & 4.22 & 5 & 2 & 9 & 97.45 & 4.18 & 1 & 4.20 & 6 & 3.96 & 5 \\
\hline 6 & Belgium & 4.11 & 4.04 & 4.18 & 6 & 5 & 9 & 96.36 & 3.83 & 13 & 4.05 & 14 & 4.05 & 3 \\
\hline 7 & Austria & 4.10 & 3.98 & 4.21 & 7 & 3 & 11 & 96.03 & 3.79 & 15 & 4.08 & 12 & 3.85 & 9 \\
\hline 8 & United Kingdom & 4.07 & 4.03 & 4.11 & 8 & 6 & 9 & 95.16 & 3.98 & 5 & 4.21 & 5 & 3.77 & 11 \\
\hline 9 & Hong K. S. China & 4.07 & 4.00 & 4.14 & 9 & 6 & 9 & 95.14 & 3.94 & 7 & 4.10 & 10 & 4.05 & 2 \\
\hline 10 & United States & 3.99 & 3.94 & 4.04 & 10 & 10 & 12 & 92.75 & 3.75 & 16 & 4.15 & 8 & 3.65 & 19 \\
\hline
\end{tabular}

Source: World Bank report 2016

Table 10: The Bottom 10 LPI Scorer Countries, 2016

\begin{tabular}{|c|c|c|c|c|c|c|c|c|c|c|c|c|c|c|}
\hline \multirow[b]{2}{*}{ S/no } & \multirow[b]{2}{*}{ Country } & \multicolumn{7}{|c|}{ Overall LPI rank } & \multicolumn{2}{|c|}{ Customs } & \multicolumn{2}{|c|}{ Infrastructure } & \multicolumn{2}{|c|}{$\begin{array}{l}\text { International } \\
\text { shipments }\end{array}$} \\
\hline & & score & $\begin{array}{l}\text { lower } \\
\text { bound }\end{array}$ & $\begin{array}{l}\text { upper } \\
\text { bound }\end{array}$ & rank & $\begin{array}{l}\text { lower } \\
\text { bound }\end{array}$ & $\begin{array}{l}\text { upper } \\
\text { bound }\end{array}$ & $\begin{array}{l}\% \text { of the } \\
\text { highest } \\
\text { performer }\end{array}$ & score & rank & score & rank & score & rank \\
\hline 151 & Zimbabwe & 2.08 & 1.77 & 2.40 & 151 & 122 & 157 & 33.55 & 2.00 & 144 & 2.21 & 123 & 2.08 & 153 \\
\hline 152 & Lao PDR & 2.07 & 1.81 & 2.33 & 152 & 133 & 157 & 33.08 & 1.85 & 155 & 1.76 & 155 & 2.18 & 148 \\
\hline
\end{tabular}




\begin{tabular}{|c|c|c|c|c|c|c|c|c|c|c|c|c|c|c|}
\hline 153 & Tajikistan & 2.06 & 1.87 & 2.26 & 153 & 138 & 156 & 32.94 & 1.93 & 150 & 2.13 & 130 & 2.12 & 151 \\
\hline 154 & Lesotho & 2.03 & 1.65 & 2.41 & 154 & 118 & 159 & 31.80 & 1.91 & 151 & 1.96 & 149 & 1.84 & 158 \\
\hline 155 & Sierra Leone & 2.03 & 1.70 & 2.36 & 155 & 130 & 159 & 31.79 & 1.91 & 152 & 2.07 & 137 & 2.31 & 138 \\
\hline 156 & Equatorial Guinea & 1.88 & 1.53 & 2.23 & 156 & 140 & 160 & 27.25 & 1.88 & 154 & 1.50 & 158 & 1.89 & 156 \\
\hline 157 & Mauritania & 1.87 & 1.52 & 2.21 & 157 & 140 & 160 & 26.84 & 2.14 & 131 & 1.54 & 157 & 2.00 & 154 \\
\hline 158 & Somalia & 1.75 & 1.37 & 2.13 & 158 & 151 & 160 & 23.16 & 1.29 & 159 & 1.57 & 156 & 1.86 & 157 \\
\hline 159 & Haiti & 1.72 & 1.55 & 1.88 & 159 & 156 & 160 & 22.20 & 1.70 & 158 & 1.47 & 159 & 1.81 & 159 \\
\hline 160 & $\begin{array}{l}\text { The Syrian Arab } \\
\text { Republic }\end{array}$ & 1.60 & 1.29 & 1.91 & 160 & 156 & 160 & 18.55 & 1.11 & 160 & 1.24 & 160 & 1.36 & 160 \\
\hline
\end{tabular}

Table 11: Top 10 Upper LPI Scorer Countries, 2018

\begin{tabular}{|c|c|c|c|c|c|c|c|c|c|c|c|c|c|c|}
\hline \multirow[b]{2}{*}{ S/no } & \multirow[b]{2}{*}{ Country } & \multicolumn{7}{|c|}{ Overall LPI rank } & \multicolumn{2}{|c|}{ Customs } & \multicolumn{2}{|c|}{ Infrastructure } & \multicolumn{2}{|c|}{$\begin{array}{l}\begin{array}{l}\text { International } \\
\text { shipments }\end{array} \\
\end{array}$} \\
\hline & & score & $\begin{array}{l}\text { lower } \\
\text { bound }\end{array}$ & $\begin{array}{l}\text { upper } \\
\text { bound }\end{array}$ & rank & $\begin{array}{l}\text { lower } \\
\text { bound }\end{array}$ & $\begin{array}{l}\text { upper } \\
\text { bound }\end{array}$ & $\begin{array}{l}\% \text { of the } \\
\text { highest } \\
\text { performer }\end{array}$ & score & rank & score & rank & score & rank \\
\hline 1 & Germany & 4.20 & 4.16 & 4.25 & 1 & 1 & 1 & 100.00 & 4.09 & 1 & 4.37 & 1 & 3.86 & 4 \\
\hline 2 & Sweden & 4.05 & 3.90 & 4.20 & 2 & 2 & 12 & 95.36 & 4.05 & 2 & 4.24 & 3 & 3.92 & 2 \\
\hline 3 & Belgium & 4.04 & 3.92 & 4.16 & 3 & 2 & 12 & 94.93 & 3.66 & 14 & 3.98 & 14 & 3.99 & 1 \\
\hline 4 & Austria & 4.03 & 3.88 & 4.17 & 4 & 2 & 14 & 94.52 & 3.71 & 12 & 4.18 & 5 & 3.88 & 3 \\
\hline 5 & Japan & 4.03 & 3.96 & 4.09 & 5 & 2 & 10 & 94.51 & 3.99 & 3 & 4.25 & 2 & 3.59 & 14 \\
\hline 6 & Netherlands & 4.02 & 3.95 & 4.09 & 6 & 2 & 11 & 94.31 & 3.92 & 5 & 4.21 & 4 & 3.68 & 11 \\
\hline 7 & Singapore & 4.00 & 3.86 & 4.13 & 7 & 2 & 15 & 93.59 & 3.89 & 6 & 4.06 & 6 & 3.58 & 15 \\
\hline 8 & Denmark & 3.99 & 3.82 & 4.16 & 8 & 2 & 17 & 93.45 & 3.92 & 4 & 3.96 & 17 & 3.53 & 19 \\
\hline 9 & UK & 3.99 & 3.93 & 4.05 & 9 & 3 & 11 & 93.30 & 3.77 & 11 & 4.03 & 8 & 3.67 & 13 \\
\hline 10 & Finland & 3.97 & 3.68 & 4.26 & 10 & 1 & 21 & 92.74 & 3.82 & 8 & 4.00 & 11 & 3.56 & 16 \\
\hline
\end{tabular}

Source: World Bank report 2018

Table 11: The Bottom 10 LPI Scorer Countries, 2018

\begin{tabular}{|c|c|c|c|c|c|c|c|c|c|c|c|c|c|c|}
\hline \multirow[b]{2}{*}{ S/no } & \multirow[b]{2}{*}{ Country } & \multicolumn{7}{|c|}{ Overall LPI rank } & \multicolumn{2}{|c|}{ Customs } & \multicolumn{2}{|c|}{ Infrastructure } & \multicolumn{2}{|c|}{$\begin{array}{l}\text { International } \\
\text { shipments }\end{array}$} \\
\hline & & score & $\begin{array}{l}\text { lower } \\
\text { bound }\end{array}$ & $\begin{array}{l}\text { upper } \\
\text { bound }\end{array}$ & rank & $\begin{array}{l}\text { lower } \\
\text { bound }\end{array}$ & $\begin{array}{l}\text { upper } \\
\text { bound }\end{array}$ & $\begin{array}{l}\% \text { of the } \\
\text { highest } \\
\text { performer }\end{array}$ & score & rank & score & rank & score & rank \\
\hline 151 & Madagascar & 2.39 & 2.19 & 2.59 & 128 & 97 & 146 & 43.40 & 2.32 & 118 & 2.16 & 128 & 2.19 & 146 \\
\hline 152 & Bolivia & 2.36 & 2.19 & 2.52 & 131 & 113 & 146 & 42.43 & 2.32 & 117 & 2.15 & 129 & 2.54 & 106 \\
\hline 153 & Guyana & 2.36 & 2.20 & 2.52 & 132 & 114 & 145 & 42.43 & 2.55 & 84 & 2.09 & 137 & 2.17 & 148 \\
\hline 154 & Fiji & 2.35 & 2.10 & 2.60 & 133 & 94 & 154 & 42.22 & 2.41 & 101 & 2.40 & 99 & 2.16 & 149 \\
\hline 155 & Mauritania & 2.33 & 2.11 & 2.55 & 135 & 108 & 153 & 41.58 & 2.20 & 128 & 2.26 & 112 & 2.19 & 145 \\
\hline 156 & Myanmar & 2.30 & 2.10 & 2.50 & 137 & 115 & 154 & 40.54 & 2.17 & 131 & 1.99 & 143 & 2.20 & 144 \\
\hline 157 & Senegal & 2.25 & 2.01 & 2.50 & 141 & 115 & 159 & 39.12 & 2.17 & 130 & 2.22 & 118 & 2.36 & 128 \\
\hline 158 & Sierra Leone & 2.08 & 1.85 & 2.31 & 156 & 137 & 160 & 33.67 & 1.82 & 155 & 1.82 & 156 & 2.18 & 147 \\
\hline 159 & Burundi & 2.06 & 1.85 & 2.28 & 158 & 139 & 160 & 33.22 & 1.69 & 159 & 1.95 & 146 & 2.21 & 139 \\
\hline 160 & Afghanistan & 1.95 & 1.79 & 2.11 & 160 & 155 & 160 & 29.63 & 1.73 & 158 & 1.81 & 158 & 2.10 & 152 \\
\hline
\end{tabular}

